\title{
Corporate Conception in Terrorism Based on Act No. 5 Of 2018
}

\author{
Parikhesit $^{1}$; Gunarto ${ }^{2}$ and Maryanto ${ }^{3}$
}

Abstract. Enforcement strategies terrorism has changed from that previously used the law enforcement strategy reactive (reactive law enforcement) to the law enforcement proactive (proactive law enforcement). Enforcement strategies are proactive expected to reach the corporate as well as those who are behind it as the founders, leaders and corporate board into the hands of the main perpetrators of criminal acts of terrorism.

The purpose of writing is to know the conception of the corporation in criminal acts of terrorism and how the system of corporate criminal liability in criminal acts of terrorism under the Act No. 5 of 2018.

Act No. 5 of 2018 recognize the corporation as a subject or as a criminal. While the forms of criminal acts committed by a corporation is the criminal acts committed by individuals. Thus the corporation can be said to be committing a crime as stipulated in the formulation of a criminal offense if the offense is committed by people on the basis of employment, or other relation, either individually or jointly, acting for and on behalf of the corporation in and outside the corporate environment.

The setting is the principal criminal fines against corporations show that the conception of the corporation in criminal acts of terrorism under the Act No. 5 of 2018 is the third model is the corporation as a maker as well as corporate responsibility.

Keywords: Corporate; Accountability; Terrorism.

\section{Introduction}

Indonesia has ratified the International Convention for the Suppression of Terrorist Bombings, 1997 (International Convention on Elimination of Terrorist Bombings, 1997) through Act No. 5 of 2006. In the legislation mentioned in article 15 that states parties shall cooperate in the prevention of terrorism crimes to take measures that can be applied, including, if necessary, adjust their legislation, to prevent and counter preparations in their respective territories for those crimes within or outside their territories, including measures to prohibit in their territories activities that are against the law of persons, groups or organizations that encourage, instigate, organize, knowingly finance or engage in conduct crimes of terrorism. ${ }^{4}$

Law enforcement strategy against terrorism refer to the development of the increase in activities in several countries in Asia, Africa, and Europe as well as in the United

\footnotetext{
${ }^{1}$ Student of Master of Law, Universitas Islam Sultan Agung Semarang and West Kalimantan Regional Police, Email: parikhesit@gmail.com

${ }^{2}$ Faculty of Law Universitas Islam Sultan Agung

${ }^{3}$ Faculty of Law Universitas Islam Sultan Agung

${ }^{4}$ Act No. 5 of 2006 on the Ratification of the International Convention for the Suppression of Terrorist Bombings, 1997 (International Convention on Elimination of Terrorist Bombings, 1997)
} 
States, requires a fundamental change both in law and in terms of politics and security. Fundamental change enforcement strategy is essential to refer to the UN high-level panel report in particular on three important pillars of the concept of Collective Security Responsibility (CSR) of all UN member states in the fight against terrorism (war on terror). The war on terrorism can not rely solely on conventional criminal law approach, which is based on the principle of mens rea and actus reus; an evil act must be proven from other than its intention as well as actions and consequences. The basic principle of conventional criminal law embodies a law enforcement is reactive (reactive law enforcement) means the law enforcement intended after the deed consequences for the victims and society. While in law enforcement practices against new terrorism began after the result of the prohibited consequences. On the basis of criminal law enforcement practices that are reactive, the state find it difficult to protect the civilian population / citizens to prevent acts of terrorism. In this case, the face of terrorism is an efficient and effective use of prevention strategies oriented forward-looking approach. This approach allows the law enforcement strategy implemented proactive (proactive law enforcement). ${ }^{5}$

Enforcement strategies are proactive (proactive law enforcement) are also expected to reach the corporate as well as those who are behind it as the founders, leaders and corporate board into the hands of the main perpetrators of criminal acts of terrorism. The problem of this paper is how the conception of the corporation in criminal acts of terrorism under the Act No. 5 of 2018 and how the system of corporate criminal liability in criminal acts of terrorism under the Act No. 5 of 2018.

\section{Discussion}

\subsection{Corporations in the conception of Terrorism by Act No. 5 of 2018}

The principle of "no punishment without fault" is a fundamental principle in criminal law. Even so fundamental, this principle has been pervasive and echoed in almost all of the teachings of the criminal law. This principle is also contained in the Dutch criminal law, known by the term "straf zonder geen Schuld" and in Germany known as "keine straf ohne Schuld". ${ }^{6}$ In criminal law in the United Kingdom also has a similar principle which in Latin reads: "actus non facit reum nisi mens sit rea" or translated into English as an act does not make a person guilty until the mind is guilty. ${ }^{7}$

Furthermore, the question arises related to the application of this principle to the corporation. This is because, the element of error is very closely linked to the attitude of the soul (intent or negligence) of humans as natuurlijke person. ${ }^{8}$ Element of intent or

\footnotetext{
${ }^{5}$ Romli Atmasasmita et.al., 2011, Naskah Akademik Perubahan UU No. 15 tahun 2003, BPHN, Jakarta, p. 126

${ }^{6}$ Muladi and Dwidja Priyatno, 2011, Pertanggungjawaban Pidana Korporasi, Kencana Prenada Media Group, Jakarta, p. 102-103

${ }^{7}$ Moeljatno, 1987, Asas-Asas Hukum Pidana, Bina Aksara, Jakarta, p. 5

8. M. van Bemmelen, 1986, Hukum Pidana 1: Hukum Pidana Material Bagian Umum, Binacipta, Bandung, p. 233
} 
negligence arise because of the mental element (menslijke psyche) and psychological elements (de psychische bedtanddelen), which is only found in humans as subjects of law (natuurlijke persoon). Thus, the corporation can be said to have no errors. ${ }^{9}$

To answer that, there are some opinions Bachelor stating that the corporation can still have errors. One of them Hulsman, Professor of Criminal Law of Rotterdam, in association preadvisnya in front of Jurists in 1966, stated that the element of fault (intent or negligence) may be held by the organs of the corporation or other workers who set the organization's policy. ${ }^{10}$ Furthermore, according to this error element sometimes appears on cooperation consciously or unconsciously from those mentioned here. So, against such persitiwa-event, there should be certain anything to do between the actions of these people. ${ }^{11}$

Van Bemmelen, in view of the intention of the corporation, found common knowledge of most members of the board of directors can be considered as kesengajaaan of the corporation, if possible as conditional intent. In addition, the light fault of any person acting for the corporation, if collected will be able to form a big mistake of the corporation itself. ${ }^{12}$ A similar opinion was also expressed by Jan Remmelink. According to Jan Remmelink corporation will always say do or not do, through or be represented by an individual. Therefore, to the corporation, the element of intent may be held to the fulfillment of the elements of the offense committed by a number of different people. These elements must have a relation to one another, so that it can be combined as a whole will meet the pattern of actions envisaged in an offense. ${ }^{13}$

Suprapto, in response to those opinions, agreed that corporations error can be taken by intentional or omissions contained on the people who become the tool. Such errors are not individual, because it relates to an entity that is collective. ${ }^{14}$

Thus, the corporation still can have an error which is taken from the board or directors in performing their duties functionaries. This is because corporations to do or not do, through or be represented by an individual. Hence the principle of "no punishment without guilt" can still apply to the corporation. This is a form of guarantee of human rights that must be protected. But in its development appears doctrines that override the principle of "no punishment without guilt" is. ${ }^{15}$

Article 1 point 9 states that every person is an individual or a corporation. ${ }^{16}$ When linked with Chapter III (Crime Terorsime) of this Act that contains the formulation of a

\footnotetext{
${ }^{9}$ Muladi da Dwidja Priyanto, Op. cit., p. 105

${ }^{10}$ Jan Remmelink, 2003, Hukum Pidana (Komentar atas Pasal-Pasal Terpenting dari Kitab UndangUndang Hukum Pidana Belanda dan Padanannya dalam Kitab Undang-Undang Hukum Pidana Indonesia), cet.1 , PT Gramedia Pustaka Utama, Jakarta,p. 108

${ }^{11} \mathrm{JM}$ van Bemmelen, op.cit., P. 237

12 Ibid.

${ }^{13}$ JanRemmelink, op.cit., p. 106-109

${ }^{14}$ Muladi and Dwidja Priyatno, op.cit., p. 105

${ }^{15}$ Aulia Ali Reza, 2015, Pertanggungjawaban Korporasi dalam Rancangan KUHP, ICJR, Jakarta, p. 11

${ }^{16}$ Act No. 52018 on Amendments to the Act No. 15 of 2003 on Stipulation of Government Regulation in lieu of Act No. 1 of 2002 on the Eradication of Terrorism Act
} 
crime, the entire formulation of the offense or a crime using the phrase "any person". This means showing that Act No. 5 of 2018 recognize the corporation as a subject or as a criminal.

Act No. 5 of 2018. It also explains what is meant by the corporation as in Article 1 point 10 which defines that the corporation is a group of persons and / or properties, either a legal entity or non-legal entity. ${ }^{17}$ This definition is the same as the corporate definition contained in article 1 point 1 of the Supreme Court Regulation No. 13 of 2016.

In the Chapter III (Crime Terorsime) Act No. 5 of 2018 which includes the formulation of criminal acts of terrorism, there are 16 chapters that constitute criminal offenses formulation. Subject of law in the formulation of such crime is everyone. So it is not munkin corporation charged with the formulation of article such offenses which are conventionally performed by a natural person.

Article 3 of the Supreme Court Regulation No. 13 of 2016 states that a criminal offense by a corporation is a criminal offense committed by the person based on the employment relationship, or based on other relationships, either individually or jointly, acting for and on behalf of corporations inside and outside the corporate environment. ${ }^{18}$ When referring to the chapter it will be seen more clearly that the article to a criminal offense as provided for in Chapter III (Terrorism) Act No. 5 of 2018 can be seen as a criminal offense committed by the corporation if done by people based on the employment relationship, or based on other relationships, either individually or jointly, acting for and on behalf of corporations inside and outside the corporate environment.

However artifacts of the article, namely Article 12A (2) and (3) that specifically included the phrase corporation. In Article 12 (A) (2) states that any person who knowingly become a member or recruit people to become members of the corporation to be established and / or court-ordered as the organization of terrorism shall be punished by imprisonment of at least 2 (two) years and a maximum 7 (seven) years. ${ }^{19}$ Prohibited in the formulation of this criminal offense essence is a member or recruit people to become members of the corporation that has been designated as a terrorist organization.

While Article 12A paragraph (3) states that the founder, leader, administrator, or the person who controls the corporation referred to in paragraph (2) shall be punished with imprisonment of minimum 3 (three) years and a maximum of twelve (12) years. ${ }^{20}$ The formulation of this criminal act is for the founder, leader, manager or person in control of a corporation or a terrorist organization. Prohibited in the

\footnotetext{
17 Ibid.

${ }^{18}$ Indonesian Supreme Court Regulation No. 13 of 2016 on Procedures for Case Management Corporate Crime

${ }^{19}$ Act No. 52018 on Amendments to the Act No. 15 of 2003 on Stipulation of Government Regulation in lieu of Act No. 1 of 2002 on the Eradication of Terrorism Act

${ }^{20}$ Ibid.
} 
formulation of this criminal act is the essence of corporate control which is a terrorist organization.

Related criminal liability by a corporation, article 3 of the Supreme Court Regulation No. 13 of 2016 explained that the criminal action by the Corporation constitute a criminal offense committed by the person based on the employment relationship, or based on other relationships, either individually or jointly, acting for and on behalf of the Corporation within and outside the Corporate Environment. ${ }^{21}$

Act No. 5 of 2018 claimed to have done the expansion of criminal liability of corporations charged to the founder, leader, administrator, or the person who directs the corporation that are explicitly listed in Article $12 \mathrm{~A}$ paragraph (3) ${ }^{22} \mathrm{But}$ actually, if we understand the conception of criminal acts committed by a corporation as stipulated in the Supreme Court No. 13 of 2016 described above, although not explicitly regulated in Article 12A paragraph (3) of Act No. 5 of 2018, the founders, leaders, administrators, or those who direct the corporation still be subject to criminal sanctions.

This is confirmed in article 17, paragraph (2) which says that the criminal acts of terrorism carried out by the corporation if the offense is committed by good people based on work relations and other relations, act in the corporate environment either individually or together. ${ }^{23}$

Based on the above discussion, it is known that Act No. 5 of 2018 recognize the corporation as a subject or as a criminal. While the criminal acts committed by the corporation in the Act No. 5 of 2018. This is a criminal offense committed by a natural person. Thus the corporation can be said to be committing a crime as stipulated in the formulation of a criminal offense if the offense pidan is done by people based on the employment relationship, or based on other relationships, either individually or jointly, acting for and on behalf of the corporation in and outside the corporate environment.

\subsection{Corporate Accountability System in Criminal Acts of Terrorism by Act No. 5 of 2018}

There are three models of corporate criminal liability in Indonesia as stated by Mardjono Reksodiputro as follows: $:^{24}$

- Board makers and administrators corporation as the corporation responsible

- Corporations as makers and administrators responsible

- The corporation as a maker as well as corporate responsibility.

\footnotetext{
${ }^{21}$ Indonesian Supreme Court Regulation No. 132016 on Procedures for Case Management Corporate Crime

${ }^{22}$ Act No. 52018 on Amendments to the Act No. 15 of 2003 on Stipulation of Government Regulation in lieu of Act No. 1 of 2002 on the Eradication of Terrorism Act

23 Ibid.

${ }^{24}$ Mardjono Reksodiputro, 1989, dalam makalahnya "Pertangungjawaban Pidana Korporasi dalam Tindak Pidana Korporasi", FH-UNDIP, Semarang, p. 9
} 
In the first model of the criminal liability corporation that acts as the caretaker makers and corporate officials are also responsible. To the board of the corporation is charged to certain obligations, even though the actual obligation is the obligation of the corporation. ${ }^{25}$ If the board does not meet these obligations then he will be convicted. Model of the first corporate criminal liability is contained in the Indonesian Penal Code in force today. ${ }^{26}$ If you look at the contents of the Criminal Code it will not be found Article concerning criminal offenses committed by corporations and corporate criminal liability. As for the offense relating to the corporation, set on the criminal acts committed by the management of corporate and criminal liability.

In the model of corporate criminal liability that both the corporation as a legal subject is already known, so the corporation has been recognized capable to commit a criminal act, but the responsibility is borne by the board. ${ }^{27}$ Muladi and Dwidja found criminal liability models are designated as a responsible steward of what is deemed committed by a corporation, that is what is done by the corporation under the authority fittings based bylaws. ${ }^{28}$ More specifically, that the board or leader of the corporation is responsible for acts committed by a person or persons, which is considered as an act of a corporation, whether he knew it or not. This is due to the obligations inherent in the board or the leader.

In looking at the shape of the rules that have adopted a model of corporate criminal liability, Mardjono Reksodiputro have different views. According to the Criminal Code already adopted this model of criminal responsibility. This is because he saw one of the provisions in the Criminal Code concerning the criminal liability of corporate officials, namely Article 59 through a different interpretation. According to this provision stipulates that the corporation can commit criminal acts, only accountability is charged to the board unless the board is able to prove he was not involved. ${ }^{29}$

In the model of corporate criminal liability is the third position of the corporation as a legal subject can be said to have fully recognized. This is because the corporation has been regarded as the creator, and for him also should be accountable ${ }^{30}$. The rules were first adopted the model of corporate criminal liability in Indonesia is Hoarding of Goods Act $1951 .{ }^{31}$ But the new model of criminal responsibility is widely known through the Law of Economic Crime in 1955. ${ }^{32}$

To determine the model of corporate responsibility in the criminal acts of terrorism under the Act No. 5 of 2018, it is necessary to look at the article 17 of Act No. 5 of 2018 explains that in the case of criminal acts of terrorism carried out by or on behalf of a corporation, then the charges and of sentences made against the corporation and / or

\footnotetext{
${ }^{25}$ Muladi and Dwidja Priyatno, op.cit., p. 86

${ }^{26}$ Mardjono Reksodiputro, op.cit., p. 3

${ }^{27}$ Mardjono Reksodiputro., Ibid.,

${ }^{28}$ Muladi, Dwidja Priyatno, op.cit., p. 89

${ }^{29}$ Mardjono Reksodiputro, Ibid.

${ }^{30}$ Mardjono Reksodiputro, op.cit., p. 4

${ }^{31}$ Andi Hamzah, 1996, Hukum Pidana Ekonomi, ed. Revisi, Erlangga, Jakarta, p. 28

${ }^{32}$ Muladi and Dwidja Priyatno, op.cit., p. 46
} 
its officers. And article 18 paragraph (2) which states that the principal criminal which could be taken against the corporation only be sentenced to a maximum fine of Rp $1,000,000,000,000,-$ (one trillion rupiahs). ${ }^{33}$

It shows that the conception of the corporation in criminal acts of terrorism under the Act No. 5 of 2018 is the third model is the corporation as a maker as well as corporate responsibility.

There are several reasons to consider who should be held accountable to the corporation. Article 4 (2) of the Regulation of Supreme Court No. 13 of 2016 states that the convict against the corporation, the judge can assess corporate error by: ${ }^{34}$

- Corporations can benefit or the benefit of a criminal offense or criminal act was committed for the benefit of the corporation;

- The corporation fail to prevent crime;

- The corporation does not undertake the necessary measures for the prevention, preventing a greater impact and ensure compliance with applicable laws and regulations in order to avoid the occurrence of a crime.

When comparing the three reasons above the corporate conception contained in Act No. 5 of 2018, then the third reason is far beyond the reason the corporation / organization terrorism. Corporations that commit terrorist acts not only benefit, neglecting or not prevention, but the corporation / organization terrorism was designed with the purpose of committing criminal acts of terrorism.

\section{Closing}

- Based on the above discussion, it is known that Act No. 5 of 2018 recognized the corporation as a subject or as a criminal. While the criminal acts committed by the corporation in the Act No. 5 of 2018. This is a criminal offense committed by a natural person. Thus the corporation can be said to be committing a crime as stipulated in the formulation of a criminal offense if the offense pidan is done by people based on the employment relationship, or based on other relationships, either individually or jointly, acting for and on behalf of the corporation in and outside the corporate environment.

- Act No. 5 of 2018 stating that the corporation may be subject to criminal subject to a fine. It shows that the conception of the corporation in criminal acts of terrorism under the Act No. 5 of 2018 is the third model is the corporation as a maker as well as corporate responsibility.

\section{Bibliography}

[1] Andi Hamzah, 1996, Hukum Pidana Ekonomi, ed. Revisi, Erlangga, Jakarta, h. 28

\footnotetext{
${ }^{33}$ Act No. 52018 on Amendments to the Act No. 15 of 2003 on Stipulation of Government Regulation in lieu of Act No. 1 of 2002 on the Eradication of Terrorism Act

${ }^{34}$ Indonesian Supreme Court Regulation No. 132016 on Procedures for Case Management Corporate Crime
} 
[2] Aulia Ali Reza, 2015, Pertanggungjawaban Korporasi dalam Rancangan KUHP, ICJR, Jakarta.

[3] J. M. van Bemmelen, 1986, Hukum Pidana 1: Hukum Pidana Material Bagian Umum, Binacipta, Bandung.

[4] Jan Remmelink, 2003, Hukum Pidana (Komentar atas Pasal-Pasal Terpenting dari Kitab Undang-Undang Hukum Pidana Belanda dan Padanannya dalam Kitab Undang-Undang Hukum Pidana Indonesia), cet.1, PT Gramedia Pustaka Utama, Jakarta.

[5] Mardjono Reksodiputro, 1989, dalam makalahnya "Pertangungjawaban Pidana Korporasi dalam Tindak Pidana Korporasi", FH-UNDIP, Semarang.

[6] Moeljatno, 1987, Asas-Asas Hukum Pidana, Bina Aksara, Jakarta.

[7] Muladi dan Dwidja Priyatno, 2011, Pertanggungjawaban Pidana Korporasi, Kencana Prenada Media Group, Jakarta.

[8] Romli Atmasasmita et.al., 2011, Naskah Akademik Perubahan UU No. 15 tahun 2003, BPHN, Jakarta.

[9] Act No. 5 of 2006 on the Ratification of the International Convention for the Suppression of Terrorist Bombings, 1997 (International Convention on Elimination of Terrorist Bombings, 1997)

[10] Act No. 5 of 2018 on Amendments to the Act No. 15 of 2003 on Stipulation of Government Regulation in lieu of Act No. 1 of 2002 on the Eradication of Terrorism Act

[11] Indonesian Supreme Court Regulation No. 13 of 2016 on Procedures for Case Management Corporate Crime. 